\title{
PENGARUH STRUKTUR MODAL, CURRENT RATIO, UKURAN PERUSAHAAN TERHADAP NILAI PERUSAHAAN PADA SEKTOR MAKANAN DAN MINUMAN DI BURSA EFEK INDONESIA PADA TAHUN 2013-2018
}

\author{
${ }^{1}$ Aulia Zuhra Nasution, ${ }^{2}$ Jamaluddin, ${ }^{3}$ Jane Caterine Sihombing, ${ }^{4}$ Chery Adita Anjani Beru Sinulingga \\ 1,2,3,4 Universitas Prima Indonesia \\ Email: 1auliazuhranst@gmail.com, 2jamalunpri@gmail.com, ${ }^{3}$ janesihombing01@gmail.com, \\ ${ }^{4}$ cheryaditaanjani@yahoo.co.id
}

\begin{abstract}
This study aims to determine the effect of capital structure, current ratio, company size on company value in the food and beverage sector 2013-2018. The data used in this study are secondary data in the form of 20132018 financial statements. The method used is multiple linear regression analysis using the help of Microsoft Excel 2013 and SPSS (Statistical Package For The Social Science) version 20 with the stepwise method. The results showed that the influential variables namely the current ratio had a positive and significant effect on firm value. While the capital structure partially does not affect the value of the company. While the company size variable has no effect on firm value. Hypothesis testing also shows that simultaneous capital structure, current ratio, and firm size affect firm value. The hypothesis determination coefficient value uses Adjusted R Square 0.14 or $14 \%$, which means that changes in firm value variables can be explained by variations in capital structure, current ratio, and firm size variables, while the remaining $86 \%$ is another variable not proposed in this study.
\end{abstract}

Keywords : Capital Structure, Current Ratio, Size Company, Company Value

\begin{abstract}
ABSTRAK
Penelitian ini bertujuan untuk mengetahui pengaruh struktur modal, current ratio, ukuran perusahaan terhadap nilai perusahaan pada sektor makanan dan minuman tahun 2013-2018. Data yang digunakan dalam penelitian ini adalah data sekunder berupa laporan keuangan tahun 2013-2018. Metode yang digunakan adalah analisis regresi linear berganda dengan menggunakan bantuan program Microsoft Excel 2013 dan SPSS (Statistical Package For The Social Science) versi 20 dengan metode stepwise. Hasil penelitian menunjukkan bahwa variabel yang berpengaruh yaitu current ratio berpengaruh positif dan signifikan terhadap nilai perusahaan. Sedangkan struktur modal secara parsial tidak berpengaruh terhadap nilai perusahaan. Sedangkan variabel ukuran perusahaan tidak berpengaruh terhadap nilai perusahaan. Pengujian hipotesis juga menunjukkan bahwa secara simultan struktur modal, current ratio, dan ukuran perusahaan berpengaruh terhadap nilai perusahaan. Nilai koefisien determinasi hipotesis menggunakan Adjusted R Square 0,14 atau 14\% yang berarti perubahan variabel nilai perusahaan dapat dijelaskan oleh variasi variabel struktur modal, current ratio, dan ukuran perusahaan, sedangkan sisanya sebesar $86 \%$ merupakan variabel lain yang tidak diajukan dalam penelitian ini.
\end{abstract}

Kata Kunci : Struktur Modal, Current Ratio, Ukuran Perusahaan, Nilai Perusahaan. 


\section{PENDAHULUAN}

Industri merupakan suatu kegiatan untuk mengelolah bahan mentah atau barang setengah jadi menjadi barang jadi barang jadi yang memiliki nilai tambah untuk mendapatkan keuntungan. Industri makanan dan minuman adalah salah satu industri yang berkembang sangat pesat di seluruh dunia, termasuk di Indonesia. Berbagai jenis makanan dan minuman dengan tampilan yang menarik terus diproduksi demi meningkatkan nilai estetika dan daya tarik konsumen. Proses produksi makanan dan minuman meliputi pemilihan bahan baku, proses pengolahan makanan dan minuman, pengujian kualitas makanan dan minuman, pengemasan hingga proses distribusi makanan dan minuman.

Salah satu tujuan perusahaan yaitu dengan cara memaksimumkan nilai perusahaan. Nilai perusahaan memiliki pengaruh besar terhadap keputusan investasi para investor, karena nilai perusahaan dapat mencerminkan kestabilan keuangan dan tingkat risiko yang dihadapi perusahaan.

Nilai perusahaan bisa dilihat melalui kemampuan perusahaan membayar dividen. Nilai perusahaan akan meningkat jika dividen juga meningkat. Nilai perusahaan dapat menjadi presepsi investor terhadap tingkat keberhasilan perusahaan yang biasanya dikaitkan dengan harga saham. Jika harga saham tinggi maka nilai perusahaan juga tinggi. Beberapa faktor terdapat mengukur nilai perusahaan antara lain struktur modal, current ratio dan ukuran perusahaan. Faktor-faktor tersebut dapat mempengaruhi penurunan nilai perusahaan, Sehingga Struktur modal berperan penting bagi perusahaan karena baik buruknya perusahaan struktur modal akan mempunyai efek langsung terhadap posisi finansial perusahaan, terutama dengan adanya utang yang sangat besar akan memberikan beban kepada perusahaan di mana semakin besar rasio tersebut maka semakin besar penggunaan dana utang atas ekuitas perusahaan, yang nantinya akan berpengaruh pada persediaan dana dalam memenuhi pendanaan perusahaan. Seluruh dana berupa total asset yang dimiliki perusahaan untuk memenuhi pendanaan perusahaan dapat mencerminkan ukuran perusahaan. Secara logika, bahwa ukuran perusahaan yang besar dan terus tumbuh bisa menggambarkan tingkat profit yang mendatang, kemudahan pembiayaan ini bisa mempengaruhi nilai perusahaan dan dianggap sebagai informasi yang baik bagi investor. Kebebasan yang dimiliki manajemen akan sebanding dengan kekhawatiran yang dirasakan oleh pemilik atas assetnya, karena investor tidak mengetahui dengan pasti hasil yang diperoleh dari investasi yang mereka lakukan dengan adanya bayang bayang risiko di masa depan.

semakin maksimal harga saham, maka semakin meningkatnya permintaan atas saham tersebut yang akan mempengaruhi nilai perusahaan di mata investor, dan Current Ratio mampu menggambarkan suatu perusahaan dalam memenuhi kewajiban jangka pendek nya secara lancar dan tepat waktu sehingga likuiditas sering disebut short term liquidity. Current ratio merupakan indikator mengenai kemampuan perusahaan untuk membayar semua kewajiban nya. Ketidakmampuan perusahaan dalam membayar semua kewajiban nya akan memberikan pandangan negatif, bahwa perusahaan mengalami 
masalah keuangan. Sehingga kepercayaan investor semakin berkurang dan mempengaruhi tinggi rendahnya nilai perusahaan.

Untuk mengetahui skala ukuran perusahaan dapat dilihat dari total asset yang berguna untuk kegiatan operasi perusahaan. Dengan total asset yang besar maka pihak manajemen perusahaan lebih leluasa dalam menggunakan asset yang ada. Pada sisi manajemen terdapat kemudahan dalam mengendalikan perusahaan sehingga dapat meningkatkan nilai perusahaan.

Pada perusahaan makanan dan minuman yang terdaftar di bursa efek Indonesia pada periode 2013-2018 diketahui bahwa nilai perusahaan PT Ultra Jaya Milk Tbk pada tahun 2014 senilai Rp.3.720 dan pada tahun 2015 senilai Rp.3.945 yang mengalami kenaikan sebesar Rp.225. Harga Saham PT Mayora Indah Tbk pada tahun 2014 senilai Rp.20.900 dan pada tahun 2015 senilai Rp.30.500 yang mengalami kenaikan sebesar Rp.9.600. Harga saham PT Multi Bintang Indonesia Tbk pada tahun 2014 senilai Rp.11.950 dan pada tahun 2015 senilai Rp.8.200 yang mengalami penurunan sebesar Rp 3.750. Harga Saham PT Siantar Top Tbk pada tahun 2014 sebesar Rp.2.880 dan pada tahun 2015 senilai Rp.3.015 yang mengalami kenaikan sebesar Rp. 135.

Dari fenomena tersebut dapat dilihat pergerakan harga saham pada sub sektor makanan dan minuman yang mengalami perubahan setiap tahunnya. Hal ini dapat dipengaruhi oleh beberapa factor yang ada pada indikator yang digunakan untuk mengukur tingkat kesetahan sub sektor makanan dan minuman yaitu struktur modal, ukuran perusahaan dan risiko perusahaan.

\section{LANDASAN TEORI}

\subsection{Struktur Modal}

Struktur modal adalah komposisi saham biasa, saham preferen dan berbagai kelas seperti itu, laba yang ditahan, dan hutang jangka panjang yang dipertahankan oleh satu kesatuan usaha dalam mendanai aktiva (Irham Fahmi,2017:106).

$$
\text { - } \quad \text { DER }=\frac{\text { Total Liabilities }}{\text { Stockholders' } \text { equity }^{-}}
$$

\subsection{Current Ratio}

Fahmi (2017:87) menyatakan bahwa rasio likuiditas adalah gambaran kemampuan suatu perusahaan dalam memenuhi kewajiban jangka pendeknya secara lancar dan tepat waktu sehingga likuiditas sering disebut short term liquidity.

$$
\text { - } \text { Current Ration }=\frac{\text { Current Assets }}{\text { Current Liabilitas }}
$$




\subsection{Ukuran Perusahaan}

Ukuran Perusahaan adalah suatu skala di mana dapat diklasifikasikan besar kecilnya perusahaan menurut berbagai cara antara lain dengan total asset, nilai pasar saham, dan lain lain (prasetyorini,2013).

- $\quad$ Size $=$ Ln of total aktiva

\section{METODE PENELITIAN}

\subsection{Tempat dan Waktu}

Penelitian dilakukan terhadap Sektor makanan dan minuman yang terdaftar di Bursa Efek Indonesia pada periode 2013 - 2018. Menggunakan data sekunder yang diakses melalui situs www.idx.co.id dan www.idnfinancials.com. Pendekatan penelitian ini menggunakan penelitian kuantitatif dan jenis penelitian statistik deskriptif.

\subsection{Populasi dan Sampel}

Populasi dalam penelitian ini adalah Sub Sektor makanan dan minuman yang terdaftar di Bursa Efek Indonesia periode 2013 - 2018 sebanyak 21 perusahaan. Penarikan sampel menggunakan teknik purposive sampling. Purposive sampling adalah memilih sampel dari suatu populasi berdasarkan pertimbangan tertentu, baik pertimbangan ahli maupun pertimbangan ilmiah. (Juliandi dan Irfan 2013:58). Penelitian menggunakan kriteria :

- Sub Sektor makanan dan minuman yang terdaftar di bursa Efek Indonesia periode 20132018

- Sub Sektor makanan dan minuman yang mempublikasikan laporan keuangan selama periode $2013-2018$

- Sub Sektor makanan dan minuman yang mengalami laba selama periode 2013-2018

- Dari kriteria diatas didapat sampel sebanyak 11 perusahaan dengan periode waktu 6 tahun, sehingga jumlah data $11 \times 6$ tahun $=66$ data .

\section{HASIL DAN PEMBAHASAN}

\subsection{Hasil}

\subsubsection{Statistik Deskriptif}

\section{Tabel 1}

Statistik Deskriptif 


\begin{tabular}{|l|l|l|l|l|l|}
\hline & $\mathrm{N}$ & Minimum & Maximum & Mean & Std. Deviation \\
\hline LN_DER & 66 & 16.88 & 21.83 & 20.1606 & 1.06204 \\
LN_CR & 66 & 16.55 & 22.88 & 21.1179 & 1.07866 \\
LN_LN & 66 & 19.02 & 21.84 & 21.2424 & .82906 \\
LN_PER & 66 & 16.38 & 22.90 & 20.8956 & 1.56677 \\
Valid N (listwise) & 66 & & & & \\
\hline
\end{tabular}

Dai hasil statistik deskriptif pada tabel 1 diatas, dapat dijelaskan bahwa :

A. Variabel DER memilki sampel sebanyak 66 dengan nilai minimum 16,88, dan nilai maksimum 21,83 sedangkan nilai rata-rata 20,1606 dengan standar deviasi 1,06204.

B. Variabel CR memilki sampel sebanyak 66 dengan nilai minimum 16,88, dan nilai maksimum 22,88 sedangkan nilai rata-rata 21,1179 dengan standar deviasi 1,07866.

C. Variabel LN memilki sampel sebanyak 66 dengan nilai minimum 19,02, dan nilai maksimum 21,84 sedangkan nilai rata-rata 21,2424 dengan standar deviasi 0,82906.

D. Variabel PER memilki sampel sebanyak 66 dengan nilai minimum 16,38, dan nilai maksimum 22,90 sedangkan nilai rata-rata 20,8956 dengan standar deviasi 1,56677.

\subsection{Uji Asumsi Klasik}

\subsubsection{Uji Normalitas}

- Grafik Histogram

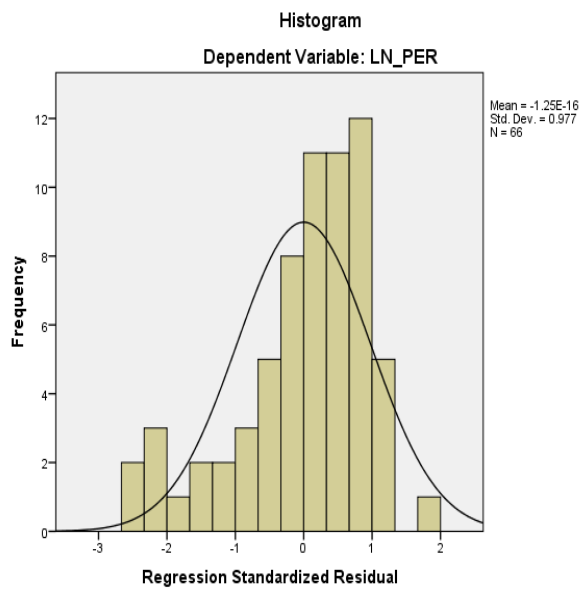

Gambar 1

Uji Normalitass Histogram

Dapat dilihat pada gambar 1 diatas bahwa grafik histrogram menunjukkan berdistibusi normal. Hal ini dapat dilihat dari kurva yang berbentuk seperti lonceng terbalik.

- Normal Probability Plot 


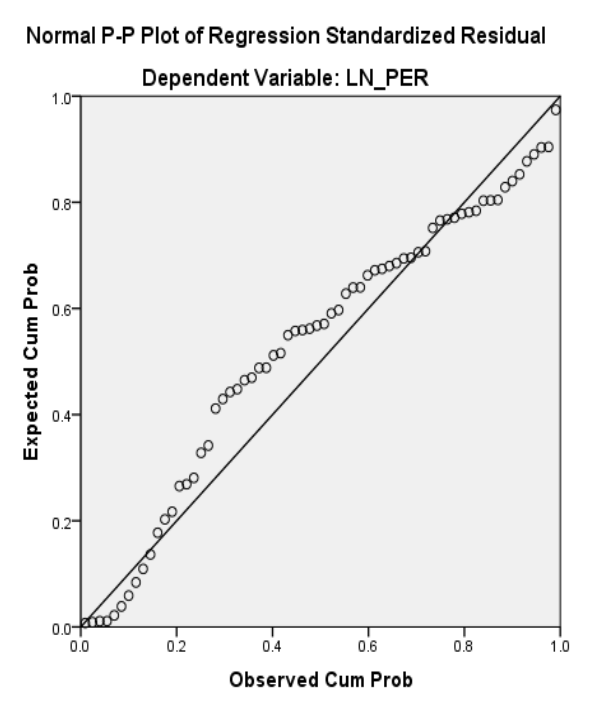

Gambar 2

Uji Normalitas Probability Plot

Pada gambar 2 dapat dilihat gafik probability plot menunjukkan gambar pola data yang baik, karena titik-titik menyebar di garis diagonal, dan mengikuti arah garis diagonal, baik yang diatas maupun dibawah garis diagonal.

- Uji Normalitas Kolmogorov Smirnov

Tabel 2

Uji Normalintas Kolmogorov Smirnov

One-Sample Kolmogorov-Smirnov Test

\begin{tabular}{|ll|r|}
\hline & & \multicolumn{1}{|c|}{$\begin{array}{c}\text { Unstandardized } \\
\text { Residual }\end{array}$} \\
\hline N & Mean & 66 \\
Normal Parameters ${ }^{\mathrm{a},}$ & $0 \mathrm{E}-7$ \\
& Std. Deviation & 1.45254511 \\
& Absolute & .140 \\
Most Extreme Differences & Positive & .076 \\
& Negative & -.140 \\
Kolmogorov-Smirnov Z & & 1.135 \\
Asymp. Sig. (2-tailed) & & .152 \\
\hline
\end{tabular}

a. Test distribution is Normal.

b. Calculated from data.

Berdasarkan hasil tabel 2 kolmogorov smirnov sebesar 1.135 dengan nilai signifikan atau Asymp Sig (2-tailed) sebesar 0,152 hasil tersebut lebih besar dari 0,05 yang artinya bahwa data berdistribusi normal.

\subsubsection{UJI MULTIKOLINIERITAS}

Tabel 3

88 | Jurnal Akuntansi AKTIVA 


\section{Uji Multikolineritas}

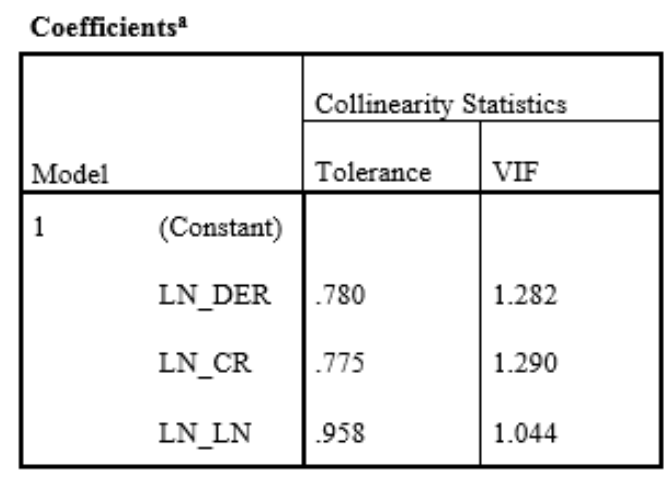

a. Dependent Variable: LN_PER

Berdasarkan hasil uji diatas diketahui bahwa nilai tolerance semua variabel independen berada diatas 0,10 yaitu DER sebagai X1 sebesar 0,780, CR sebagai X2 sebsar 0,775, dan untuk LN sebagai $\mathrm{X} 3$ sebesar 0,958. Sedangkan nilai VIF antara variabel X1,X2 dan X3 berada di bawah 10. Jadi dapat disimpulkan bahwa penelitian ini berdasarkan nilai Tolerance Value tidak terjadi multikolonieritas.

\subsubsection{UJI HETEROSKEDASTISITAS}

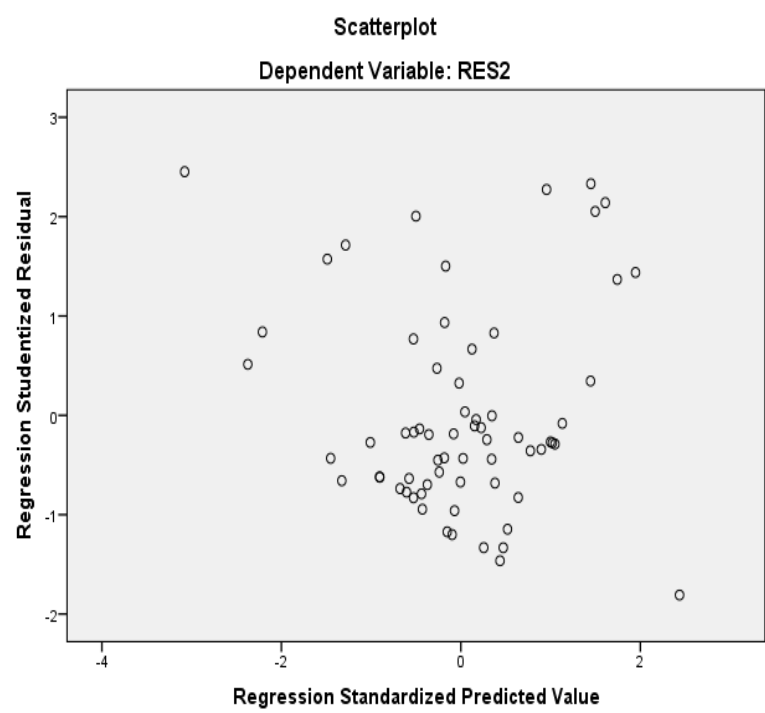

Gambar 3

Uji Heteroskedastisitas dengan Scatterplot

Tabel 4

Uji White 
Model Summary ${ }^{b}$

\begin{tabular}{|c|c|c|c|c|}
\hline Model & $\mathrm{R}$ & $\begin{array}{c}\mathrm{R} \\
\text { Square }\end{array}$ & $\begin{array}{c}\text { Adjusted R } \\
\text { Square }\end{array}$ & Std. Error of the Estimate \\
\hline 1 & $.242^{2}$ & .059 & .013 & 7702592176928254000.00000 \\
\hline
\end{tabular}

a. Predictors: (Constant), LN, CR, DER

b. Dependent Variable: RES2

Berdasarkan hasil dari uji white diatas untuk menghitung nilai $\mathrm{R}$ square dengan rumus $\mathrm{n} \times \mathrm{R}^{2}$ yang di mana $\mathrm{R}$ square $\left(\mathrm{R}^{2}\right)$ dengan nilai 0,59 dan $\mathrm{n}$ dengan nilai 66 maka perhitungan $\mathrm{R}$ square nya adalah $66 \times 0,059=3,894$. Jadi nilai $\mathrm{R}^{2}$ hitungannya adalah 3,894 sedangkan untuk mengetahui nilai $\mathrm{R}^{2}$ tabelnya dari $\mathrm{df}=\mathrm{k}-1$ yang artinya $\mathrm{k}=3-1$ sehingga nilai diatas bahwa $\mathrm{R}^{2}$ hitung $<\mathrm{R}^{2}$ tabel $(3,894$ $<5,99146$ ) maka artinya tidak ada gejala heteroskedastisitas.

\subsubsection{UJI AUTOKORELASI}

Tabel 5

Uji Autokorelasi

Model Summary

\begin{tabular}{|l|l|l|l|l|l|}
\hline Model & $\mathrm{R}$ & R Square & $\begin{array}{l}\text { Adjusted } \\
\text { Square }\end{array}$ & $\begin{array}{l}\mathrm{R} \\
\text { Std. Error of the Durbin-Watson } \\
\text { Estimate }\end{array}$ & \\
\hline 1 & $375^{\mathrm{a}}$ & .140 & .099 & 1.48727 & 1.764 \\
\hline
\end{tabular}

a. Predictors: (Constant), LN_LN, LN_DER, LN_CR

b. Dependent Variable: LN_PER

Berdasarkan 5 diatas, dapat dilihat bahwa nilai DW sebesar 1,764 dengan melihat tabel uji dw dengan tingkat signifikan 0,05 untuk jumlah variebel bebas $=3$ dan jumlah sampel 66. Maka dari tabel DW diperoleh nilai DU sebesar 1,6974 maka dapat disimpulakan bahwa data terbebas dari masalah uji autokorelasi karena DU < DW < 4-DU atau 1,6974 < 1,764 <2,3026 .

\subsubsection{Hasil Analisis Data}

Tabel 6

UJI REGRESI LINEAR BERGANDA 


Coefficients $^{\mathbf{a}}$
\begin{tabular}{|ll|r|r|}
\hline \multirow{2}{*}{} & & \multicolumn{2}{|c|}{$\begin{array}{c}\text { Unstandardized } \\
\text { Coefficients }\end{array}$} \\
\cline { 3 - 4 } Model & & \multicolumn{1}{|c|}{ B } & \multicolumn{1}{c|}{ Std. Error } \\
\hline 1 & (Constant) & 25.827 & 7.569 \\
& LN DER & .150 & .197 \\
& LN CR & -.463 & .194 \\
& LN LN & .086 & .227 \\
\hline
\end{tabular}

a. Dependent Variable: LN PER

Dari hasil diatas maka diperoleh persamaan regresi sebagai berikut :

$\mathrm{Y}=25,827-0,150 \mathrm{X} 1--0,463 \mathrm{X} 2+0,86 \mathrm{X} 3$

Dari persamaan diatas dapat diartikan sebagai berikut:

1. Nilai konstanta adalah 25,827. nilai konstan ini menunjukkan bahwa variabel bebas yaitu Struktur Modal, Current Ratio, Ukuran Perusahaan dianggap konstan atau sama dengan 0, maka nilai perusahaan meningkat sebesar $25,82 \%$.

2. Nilai Koefisien Struktur Modal adalah 0,150. Hal ini menunjukkan bahwa setiap kenaikan Struktur Modal satu satuan maka, kebijakan dividen mengalami penurunan sebesar 15.

3. Nilai koefisien Current Ratio adalah -0,463. Hal ini menunjukkan bahwa setiap kenaikan Current Ratio satu satuan maka, kebijkan dividen mengalami penurunan sebesar -46,3.

4. Nilai koefisen Ukuran Perusahaan adalah 0,086. Hal menunjukkan bahwa setiap kenaikan Ukuran Perusahaan satu satuan maka, kebijakan dividen akan mengalami kenaikan sebesar 8,6.

\subsubsection{UJI KOEFISIEN DETERMINASI}

Tabel 7

\section{Koefisien Determinisasi}

Model Summary ${ }^{b}$

\begin{tabular}{|l|l|l|l|l|}
\hline Model & $\mathrm{R}$ & R Square & Adjusted R Square & $\begin{array}{l}\text { Std. Error of the } \\
\text { Estimate }\end{array}$ \\
\hline 1 & $375^{\mathrm{a}}$ & .140 & .099 & 1.48727 \\
\hline
\end{tabular}

a. Predictors: (Constant), LN_LN, LN_DER, LN_CR

\section{b. Dependent Variable: LN_PER}

Dari hasil diatas diperoleh nilai R Square yaitu sebesar 0,140 atau $14 \%$ besarnya variabel dependen dapat menjelaskan variabel independen, sisa $86 \%$ dijelaskan oleh variabel lainnya yang tidak diteliti dalam penelitian ini.

\subsubsection{PENGUJIAN HIPOTESIS SECARA SIMULTAN (UJI F)}




\section{Tabel 8}

\section{Uji F Secara Simultan}

\section{ANOVA $^{\mathrm{a}}$}

\begin{tabular}{|c|c|c|c|c|c|c|}
\hline \multicolumn{2}{|c|}{ Model } & $\begin{array}{l}\text { Sum of } \\
\text { Squares }\end{array}$ & $\mathrm{df}$ & $\begin{array}{l}\text { Mean } \\
\text { Square }\end{array}$ & $\mathrm{F}$ & Sig. \\
\hline \multirow[t]{3}{*}{1} & Regression & 22.418 & 3 & 7.473 & 3.378 & $.024^{\mathrm{b}}$ \\
\hline & Residual & 137.143 & 62 & 2.212 & & \\
\hline & Total & 159.561 & 65 & & & \\
\hline
\end{tabular}

\section{a. Dependent Variable: LN_PER \\ b. Predictors: (Constant), LN_LN, LN_DER, LN_CR}

Dari hasil diatas diperoleh hasil $\mathrm{F}_{\text {hitung }}$ sebesar 3,378 dan $\mathrm{F}_{\text {tabel }}$ 2,75 dengan tingkat signifikansi sebesar 0,024 di mana 3,378 $<2,75$ dan signifikansi 0,024 > 0,05. Df1 (jumlah variabel -1 ) $=3$ dan df2 $(n-k-1)=(66-3-1)=62$ maka diperoleh $F_{\text {tabel }} 2,75$. Artinya maka DER,CR dan LN berpengaruh namun tidak signifikan terhadap PER.

\subsubsection{PENGUJIAN HIPOTESIS SECARA PARSIAL (UJI t)}

\section{Tabel 9}

\section{Uji T Secara Parsial}

\begin{tabular}{|c|c|c|c|c|c|}
\hline \multicolumn{6}{|c|}{ Coefficients $^{\mathrm{a}}$} \\
\hline \multirow[b]{2}{*}{ Model } & \multicolumn{2}{|c|}{$\begin{array}{c}\text { Unstandardized } \\
\text { Coefficients }\end{array}$} & \multirow{2}{*}{$\begin{array}{c}\text { Standardized } \\
\text { Coefficients } \\
\text { Beta } \\
\end{array}$} & \multirow[b]{2}{*}{$\mathrm{t}$} & \multirow[b]{2}{*}{ Sig. } \\
\hline & $\mathrm{B}$ & Std. Error & & & \\
\hline 1 (Constant) & 25.827 & 7.569 & & 3.412 & .001 \\
\hline LN DER & .150 & .197 & .102 & .765 & .447 \\
\hline LN CR & -.463 & .194 & -.319 & -2.386 & .020 \\
\hline LN LN & .086 & .227 & .045 & .377 & .707 \\
\hline
\end{tabular}

a. Dependent Variable: LN_PER

$\mathrm{Df}=\mathrm{n}-\mathrm{k}-1(66-3-1)=62$ dengan signifikansi 0,05

a. Pengujian secara parsial (Uji t) untuk DER terhadap nilai perusahaan adalah nilai $T_{\text {hitung }}$ sebesar 0,765 sedangkan nilai $\mathrm{T}_{\text {tabel }}$ sebesar 1,99897 di mana 0,765 $<1,99897$ dengan nilai signifikansi 0,447 > 0,05. Artinya $\mathrm{H}_{0}$ diterima $\mathrm{H}_{\mathrm{a}}$ ditolak yaitu DER secara parsial tidak berpengaruh terhadap nilai perusahaan pada Perusahaan Makanan dan Minuman yang terdaftar di Bursa Efek Indonesia periode 2013-2018

b. Pengujian secara parsial (Uji t) untuk CR terhadap nilai perusahaan adalah nilai $T_{\text {hitung }}$ sebesar -2,386, sedangkan nilai $\mathrm{T}_{\text {tabel }}$ sebesar 1,99897 di mana -2,386 > -1,99897 dengan nilai signifikansi 0,020 $<0,05$. Artinya $\mathrm{H}_{\mathrm{o}}$ ditolak $\mathrm{H}_{\mathrm{a}}$ diterima yaitu $\mathrm{CR}$ secara parsial berpengaruh Negatif dan signifikansi 
terhadap nilai perusahaan pada perusahaan Makanan dan Minuman yang terdaftar di Bursa Efek Indonesia periode 2013-2018

c. Pengujian secara parsial (Uji t) untuk $L N$ terhadap nilai perusahaan adalah nilai $\mathrm{T}_{\text {hitung }}$ sebesar 0,377, sedangkan nilai $\mathrm{T}_{\text {tabel }}$ sebesar 1,99897 di mana 0,377 < 1,99897 dengan nilai signifikansi 0,707 $>0,05$. Artinya $\mathrm{H}_{\mathrm{o}}$ diterima $\mathrm{H}_{\mathrm{a}}$ ditolak yaitu $\mathrm{LN}$ tidak berpengaruh terhadap nilai perusahaan pada perusahaan Makanan dan Minuman yang terdaftar di Bursa Efek Indonesia periode 2013-2018.

\subsection{Pembahasan Hasil Penelitian}

\subsubsection{Pengaruh Debt to Equity Ratio Terhadap Nilai Perusahaan}

Debt to Equity Ratio secara parsial tidak berpengaruh terhadap Nilai Perusahaan pada sektor makanan dan minuman di Bursa Efek Indonesia periode 2013-2018.

Hasil penelitian ini sesuai dengan penelitian Adrianus, dkk (2020) yang menyatakan bahwa perbandingan antara total utang dengan modal sendiri atau seberapa besar aktiva perusahaan dibiayai dari utang perusahaan dengan tingkat hutang yang tinggi akan mempengaruhi laba bagi perusahaan, yang mencerminkan kemampuan perusahaan dalam memenuhi semua kawajiban nya, semakin tinggi Debt to Equity Ratio menunjukkan komposisi total hutang semakin besar dibanding dengan total modal sendiri sehingga berdampak semakin besar beban perusahaan terhadap pihak luar. Tetapi hasil penelitian ini tidak sesuai dengan penelitian Desi Irayanti dan Altje L. Tumbel (2014) yang menyatakan bahwa Debt to Equity Ratio secara parsial berpengaruh signifikan terhadap nilai perusahaan makanan dan minuman.

Hal ini menunjukkan bahwa tidak semuanya DER mempunyai pengaruh positif yang signifikan hal tersebut menunjukkan bahwa setiap kenaikan DER maka nilai perusahaan akan meningkat dengan signifikan dan sebaliknya jika DER menurun yang berarti perusahaan mengurangi penggunaan hutang maka nilai perusahaan akan menurun.

\subsubsection{Pengaruh Current Ratio Terhadap Nilai Perusahaan}

Current Ratio secara parsial berpengaruh negatif dan signifikansi terhadap nilai perusahaan pada sektor makanan dan minuman di Bursa Efek Indonesia periode 2013-2018.

Hasil penelitian ini sesuai dengan penelitian Abraham Kelli Sion Watung, dkk (2016) yang menyatakan bahwa rasio yang menggambarkan kemampuan perusahaan dalam memenuhi kewajiban (utang) jangka pendek. Tetapi hasil penelitian ini tidak sesuai dengan penelitian Muhammad Faisal Kahfi, dkk (2018) yang menyatakan bahwa current ratio berpengaruh signifikan positif terhadap nilai perusahaan.

Hal ini berarti bahwa apabila current ratio mengalami perubahan sehingga tinggi rendahnya rasio ini akan mempengaruhi minat investor untuk menginvestasikan dananya. Makin besar rasio ini maka semakin efisien perusahaan dalam mendayagunakan aktiva lancar perusahaan.

\subsubsection{Pengaruh Ukuran Perusahaan Terhadap Nilai Perusahaan}


Ukuran Perusahaan secara parsial tidak berpengaruh terhadap nilai perusahaan pada sektor makanan dan minuman di Bursa Efek Indonesia periode 2013-2018.

Hasil penelitian ini sesuai dengan penelitian Selin Lumoly, dkk (2018) yang menyatakan bahwa semakin besar ukuran perusahaan, maka akan cenderungan lebih banyak investor yang menaruh perhatian pada perusahaan sehingga akan meningkatkan nilai perusahaan di mata investor. Nilai perusahaan yang meningkat dapat ditandai dengan total aktiva perusahaan yang mengalami kenaikan lebih besar dibandingkan dengan jumlah mata hutang perusahaan. Tetapi hasil penelitian ini tidak sesuai dengan penelitian Regina Rumandor, dkk (2015) yang menyatakan bahwa ukuran perusahaan berpengaruh negatif dan tidak signifikan terhadap nilai perusahaan.

Dalam hal ini dapat disimpulkan bahwa ukuran perusahaan tidak selalu mempengaruhi nilai perusahaan sehingga ukuran perusahaan berpengaruh negatif dan tidak signifikan.

\section{SIMPULAN DAN SARAN}

Secara simultan Struktur Modal, Current Ratio, Ukuran Perusahaan berpengaruh terhadap nilai perusahaan sub sektor makanan dan minuman yang terdaftar di Bursa Efek Indonesia pada periode 2013-2018. Hasil koefisien determinasi sebesar 0,140 atau sebesar 14\% maka dapat disimpulkan bahwa variabel nilai perusahaan dapat dijelaskan oleh variabel Struktur Modal, Current Ratio, Ukuran Perusahaan dan sisanya sebesar $86 \%$ di pengaruh oleh variabel lain yang tidak dijelaskan dalam penelitian ini.

Bagi peneliti, pada saat akan melakukan penelitian selanjutnya, disarankan untuk menambah variabel yang lain ataupun mengganti variabel yang tidak berpengaruh dan pemilihan variabel disesuaikan dengan masalah yang sedang diteliti.

\section{Buku dan Jurnal}

[1] Abraham Kelli Sion Watung, Ivonne S. Saerang, Hizkia H. D. Tasik (2016). Pengaruh Rasio Likuiditas, Aktivitas, Profitabilitas, Dan Struktur Aktiva Terhadap Struktur Modal Industri Barang Konsumsi Di Bursa Efek Indonesia. Jurnal EMBA. Vol 4 No.2 Juni 2016, Hal 726-737. ISSN 2303-1174.

[2] Adrianus E Dolongseda, Sri Murni, Sjendry S.R Loindong (2020). Pengaruh Struktur Modal Dan Assets Size Terhadap Profitabilitas Industri Property dan Estate Periode 2014-2017. Jurnal EMBA Vol.8 No.1 Januari Hal.2158-2168. ISSN 2303-1174.

[3] Desi Iranti, Altje L. Tumbel. (2014). Analisis Kinerja Keuangan Pengaruhnya Terhadap Nilai Perusahaan Pada Industri Makanan Dan Minuman Di BEI. Jurnal EMBA. Vol.2 No.3 September 2014, Hal. 1473-1482. ISSN 2303-1174.

[4] Dessy Handa Sari, Atim Djazuli, Siti Aisjah. (2013). Determinan Struktur Modal dan Dampaknya terhadap Nilai Perusahaan (Studi pada Perusahaan Makanan dan Minuman di Bursa Efek Indonesia). Jurnal Aplikasi Manajemen. Volume 11., No. 1, Maret 2013. ISSN: 1693- 5241. 
[5] Fahmi, Irham. (2017). Analisis Kinerja Keuangan. Bandung: Alfabeta

[6] Ghozali, Imam. (2016). Aplikasi Analisis Multivariate dengan Program IBM SPSS 23. Cetakan VIII. Semarang: Universitas Diponegoro.

[7] Hery. (2017). Kajian Riset Akuntansi. Jakarta: Grasindo

[8] Miracllyne F.G Mawei, Joy E. Tulung. (2019). Pengaruh Dewan Direksi, Ukuran Perusahaan dan Debt To Equity Ratio Terhadap Nilai Perusahaan Pada Subsektor Food And Beverage Yang Terdaftar Di Bursa Efek Indonesia. Jurnal EMBA. Vol.7 No.6 Juli 2019, Hal. 3249 - 3258. ISSN 2303-1174.

[9] Muhammad Faishal Kahfi, Dudi Pratomo, Wiwin Aminah (2018). Pengaruh Current Ratio, Debt To Equity Ratio, Total Assets Turnover Dan Return On Equity Terhadap Nilai Perusahaan.Jurnal e-Proceeding of Management Vol 5, No.1 Maret 2018, Hal 573. ISSN 23559357.

[10] Selin Lumoly, Sri Murni, Victoria N. Untu (2018). Pengaruh Likuiditas, Ukuran Perusahaan Dan Profitabilitas Terhadap Nilai Perusahaan. Jurnal EMBA. Vol 6 No.3 Juli 2018, Hal. 11081117. ISSN 2303-1174. 